\title{
Concentrations of Cadmium, Copper, and Zinc in Macrobrachium rosenbergii (Giant Freshwater Prawn) from Natural Environment
}

\author{
Farah Akmal Idrus ${ }^{1}$. Masania Mohd Basri ${ }^{1}$ - Khairul Adha A. Rahim ${ }^{1} \cdot$ Nur Syazwani Abd Rahim ${ }^{1}$. \\ Melissa Dennis Chong' ${ }^{1}$
}

Received: 20 April 2017 / Accepted: 5 January 2018

(c) Springer Science+Business Media, LLC, part of Springer Nature 2018

\begin{abstract}
This study analyzed the levels of cadmium $(\mathrm{Cd})$, copper $(\mathrm{Cu})$, and zinc $(\mathrm{Zn})$ by the flame atomic absorption spectrophotometer (FAAS), in the muscle tissues, exoskeletons, and gills from freshwater prawn (Macrobrachium rosenbergii) $(\mathrm{n}=20)$ harvested from natural habitat in Kerang River, Malaysia on 25th November 2015. Significant increase of the metals level in muscle tissue and gill $(\mathrm{r}>0.70, p<0.05)$ were observed with increase in length except for $\mathrm{Cu}$ in gills. No relationship was found between metals level in exoskeleton and length. The concentrations of $\mathrm{Cd}, \mathrm{Cu}$ and $\mathrm{Zn}$ were significantly higher $(p<0.05)$ in males (muscle tissues and exoskeleton) except for $\mathrm{Cd}$ in exoskeleton. In gills, only $\mathrm{Cu}$ was significantly higher $(p<0.05)$ in female than male. All samples contained metals below the permissible limit for human consumption (i.e., $\mathrm{Cd}<2.00 \mathrm{mg} /$ $\mathrm{kg} ; \mathrm{Cu}<30.00 \mathrm{mg} / \mathrm{kg} ; \mathrm{Zn}<150 \mathrm{mg} / \mathrm{kg}$ ). Annual metals monitoring in prawn and environmental samples is recommended to evaluate changes of metals bioaccumulation and cycling in the system, which is useful for resources management.
\end{abstract}

Keywords Freshwater prawn $\cdot$ Metals concentration $\cdot$ Sex and body length $\cdot$ Kerang River

Metals contamination in the aquatic ecosystems has become one of the greatest concerns towards the aquatic environmental bio-monitoring worldwide. Metals such as $\mathrm{Cd}$ and $\mathrm{Zn}$ had been known to occur in the phosphate fertilizers that used to enhance crop production especially in the nutrientdeficient land (Lambert et al. 2007). However, the cultivated land with the usage of phosphate fertilizers is susceptible to $\mathrm{Cd}, \mathrm{Cu}$ and $\mathrm{Zn}$ contamination because these metals are naturally present in the phosphate rocks mainly used in the production of these fertilizers (Lambert et al. 2007). Moreover, the $\mathrm{Cd}, \mathrm{Cu}$ and $\mathrm{Zn}$ absorbed by the cultivated soil can enter the river ecosystem by the leaching process and later accumulated through the food chain.

Kerang River floodplain is located in the Balai Ringin, Sarawak. Balai Ringin area was dense with mixed dipterocarp forest (Kendawang et al. 2004) and some part of oil palm plantation and cultivated area (Mohizah 2003). The basis of water quality of this river can be grouped into two

Masania Mohd Basri

masania.mohdbasri@yahoo.com

1 Faculty of Resource Science and Technology, Universiti Malaysia Sarawak, 94300 Kota Samarahan, Sarawak, Malaysia different types which are brown water and black water (Rahim et al. 2009). The black water of this river is contributed from its tributaries which flow into the brown water river. Black water or commonly known as dark 'tea' colour water column in certain river or floodplain can happen naturally in the lowland river ecosystem and usually associated with high dissolved organic matter and low dissolved oxygen level (Howitt et al. 2007). Shuhaimi-Othman et al. (2009) emphasized that in black water surrounding, metals content in the sediments were generally higher than in the underlying water column due to the conversion of dissolved to the particulate metal and indirectly shows the pollution over long time. Kerang River is generally known to have abundant of $M$. rosenbergii in their water body that provide for livelihood for people resides around Kerang River. This may indirectly cause the metals accumulation in prawn body in this river to be higher than other river.

Macrobrachium rosenbergii is a nocturnal feeders and remains half-buried in sediments during daytime to hide from direct sunlight (Murthy et al. 2012) thus being susceptible to metals accumulation. Furthermore,they serves as regional and local fisheries importance and economic value since they meet a high demand as a source of protein and international export activities (Banu and Christianus 2016; 